\title{
Increasing Transit Ridership: A Survey of Successful Transit Systems in the 1990s
}

\author{
Daniel Baldwin Hess, Allison Yoh, Hiroyuki Iseki, and Brian Taylor \\ Institute of Transportation Studies \\ University of California, Los Angeles
}

\begin{abstract}
This study examines trends in public transit ridership in the United States during the 1990s. Specifically, it focuses on agencies that increased ridership during the latter half of the decade. While transit ridership increased steadily by 13 percent nationwide between 1995 and 1999, not all systems experienced ridership growth equally. Some agencies increased ridership dramatically, some did so only minimally, and still others lost riders. What sets these agencies apart from one another? What explains the uneven growth in ridership?

To examine these questions, we conducted a nationwide survey of transit agencies that added riders during the late 1990s. Specifically, transit general managers or their designees were asked about the factors they deemed important for ridership growth in their systems. We gathered information about specific transit planning efforts and programs that are not available from aggregate data sources, like the National Transit Database (NTD).
\end{abstract}


This article reports the results of this survey and documents recent planning efforts of successful transit systems. We found that:

1. Service improvements and advertising/information programs are perceived by transit managers to have increased patronage, though opinions varied widely on how significantly such changes affected ridership.

2. While the literature generally suggests that fare changes affect ridership less than service improvements, universal fare coverage programs are widely perceived to have positively influenced ridership by the systems that implemented such programs.

3. Three factors outside of the control of transit managers and planners (population growth, economic/employment growth, and worsening traffic congestion) are frequently cited as significantly causing patronage to climb.

\section{Introduction}

The 1990s were a volatile decade for the U.S. public transit industry. Many systems lost patrons during the recession years of the early 1990s, though a few actually added riders. During the economic boom of the late 1990s, transit ridership nationwide increased steadily. But not all systems increased ridership equally; some posted dramatic ridership gains, while others actually lost riders. Although many industry insiders have theories about which transit systems have been the most successful and why, there actually has been little systematic examination of ridership growth. This study explores recent trends in public transit ridership to increase understanding of why some public transit systems have been successful at attracting new riders and others have not. As part of this research, managers of the transit systems nationwide that increased patronage during the late $1990 \mathrm{~s}$ were surveyed to explore their views of the keys to increasing patronage.

Some respondents reported that variation in transit use is largely external to transit systems and thus is outside of the control of transit managers; others reported that ridership increases on their systems resulted, at least in part, from factors internal to the agencies. In the survey reported here, we focused on internal factors that transit operators believe have been most effective in attracting and maintaining customers. In an environment of increased automobile use, some transit agen- 
cies have successfully attracted new riders by becoming more flexible, creative, and innovative in their service provision and marketing.

\section{Explaining Transit Use}

Figure 1 shows the recent trend in nationwide transit patronage over the past two decades. Several important points emerge. Overall transit use declined during the recession years of the late 1980s and early 1990s, only to rebound with the economic boom of the mid-1990s. The 9.1 billion unlinked passenger trips' in 1999 represented a 17 percent increase nationwide in just four years (APTA 1999). Per-

Figure 1. Number of unlinked transit trips on U.S. transit systems (1980-1999)

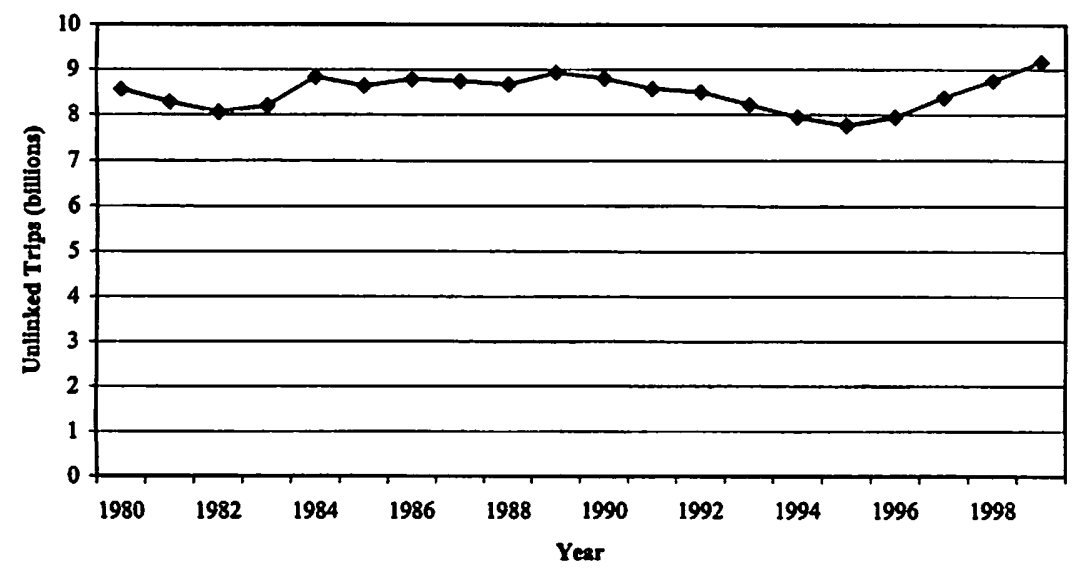

Figure 2. Annual unlinked trips per capita on U.S. transit systems (1985-1999)

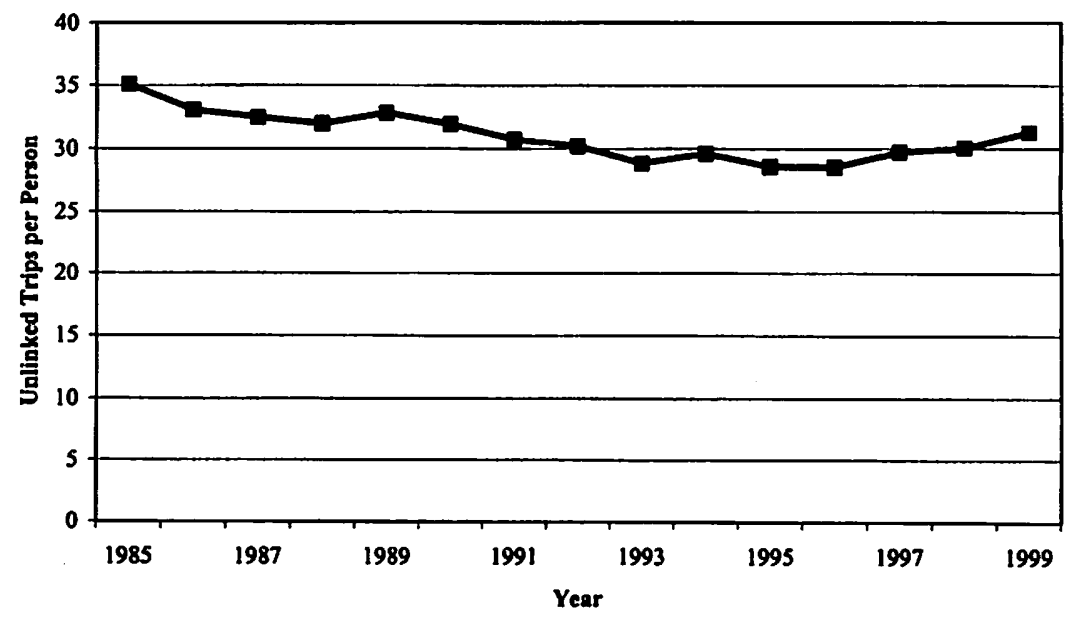


haps the most auspicious aspect of the recent upswing in transit ridership is that transit trips per capita are on the rise as well, based on projections of the 1990 U.S. Census (Figure 2). Americans took an average of 31.3 trips per capita in 1999, compared with only 28.6 trips per capita in 1995 (a $9 \%$ increase). ${ }^{2}$

While these increases in transit patronage are encouraging, transit's overall share of metropolitan travel fell throughout the 1980s and the early 1990s and does not appear to have increased, even with the recent transit ridership increase. This is because cities continue to grow, and urban travel is growing even faster. Just 1.8 percent of all person-trips in the United States were made by transit in 1995, down from a 2.2 percent share in 1983, and 2.4 percent in 1977. Nationwide, 4.5 percent of all commut trips were made by transit in 1983; by 1995, this share had fallen to 3.5 percent (Federal Highway Administration 1995; Pisarski 1996).

\section{Previous Research}

Public transit ridership is influenced by a variety of factors, both internal and external to the transit system. Internal factors are those under the purview of transit managers and policy boards, such as the quantity of service, fare structures and rates, scheduling, route design, and other aspects of service provision. Transit operators can adjust the quantity of service provided and the fare charged in an effort to attract paying customers in the most cost-effective manner possible. External factors, in contrast, are those beyond a transit agency's control, such as population and employment growth, residential and workplace locations, and factors that influence the relative attractiveness of transit (e.g., traffic congestion, gasoline prices, and parking costs). Changes in these external conditions can powerfully influence ridership. Because public transit tends to capture a relatively large share of commut trips to jobs in central business districts, downtown employment growth is strongly correlated with both the quantity of transit service and transit patronage. Further, sharply increasing unemployment rates and overall reductions in consumer spending can significantly decrease both transit ridership and revenue (Fleishman et al. 1996; Taylor and McCullough 1998).

Previous studies of transit ridership have identified several common factors that influence transit use. Among internal factors, increasing the quantity of service (in terms of service coverage and service frequency) and reducing fares are both found to have significant effects on ridership (Sale 1976; Cervero 1990). Systems with low unit costs, low fares, and low subsidies with spatially concentrated service have proven the most cost effective in increasing ridership (Hartgen and Kinnamon 1999). Kain and Liu (1996) estimate fare elasticity of ridership with respect to fare change 
to be between -0.34 and -0.44 , while the elasticity of ridership with respect to changes in revenue miles of service ranges between 0.70 and 0.89 . A few studies found that pricing schemes, such as deep discounting, ${ }^{3}$ induce significant ridership increases, because such schemes account for different sensitivity to price among various market segments. Some transit agencies provide discounted transit fares to students through partnerships with universities-university transit pass programs-and have been very successful in increasing ridership without increasing service (Brown, et al. 2001). In addition to fare policies, some studies found that the quality of service-customer and on-street service, and station and on-board safety-is more important in attracting riders than changes in fares or the quantity of service (Cervero 1990).

Among external factors studied, many researchers argue that residential and employment density are critical determinants of transit use, while the effects of landuse mix and urban design are relatively small (Crane 2000; Pushkarev and Zupan 1977). Demographic factors, such as personal income, auto ownership, and suburbanization of residential and job locations, also have been found to display significant effects on ridership (Kain and Liu 1995; Gomez-lbanez 1996). GomezIbanez (1996) found that transit ridership is strongly affected by forces beyond the transit system's control. For example, each percentage decrease in Boston's jobs reduces Massachusetts Bay Transportation Authority (MBTA) ridership by between 1.24 percent and 1.75 percent, and each percentage increase in real per capita income reduces MBTA ridership by 0.7 percent. The effects of fare and service policies are, by contrast, relatively small. A 1 percent increase in service increases ridership by only between 0.30 and 0.36 percent, and a 1 percent reduction in fares increases ridership by between 0.22 and 0.23 percent. Finally, strategies to increase parking costs or the probability of a driver incurring parking charges are found to be more effective in increasing transit mode share than increasing either the frequency or service coverage of transit (Transit Cooperative Research Program 1998).

The studies cited here adopted a wide array of methodological approaches:

1. correlation studies,

2. simple regression models,

3. multiple regression models,

4. surveys/interviews,

5. case studies, and

6. literature reviews. 
The more objective statistical analyses have typically focused on testing the relative causal influence of internal and external factors on transit ridership. Collectively, these studies have found that external factors-such as population and employment growth - have had more influence on ridership than internal factorssuch as fares and service quantities. However, these aggregate statistical analyses have been hampered by limited and incomplete data, particularly concerning the external influences on patronage. In contrast, the more subjective studies based on literature reviews, surveys/interviews, and case studies have typically sought to identify the factors thought to affect ridership. Many of these studies, however, are relatively old, and most of them do not specifically ask about perceptions of causality or the relative influence of internal or external factors. In the survey described below, these two shortcomings were specifically addressed in the research on factors influencing transit patronage.

\section{Survey Design and Response}

Data for this analysis are drawn from a national survey of managers of transit systems that increased ridership. The goal of this survey was to ask transit managers about the factors they believe were responsible for recent ridership growth on their systems and to learn about the specific policies, programs, and planning efforts conducted on these increasingly well-patronized transit systems. To identify which transit systems were most successful at increasing ridership during the late 1990s, the NTD maintained by the Federal Transit Administration (FTA) was used to measure national trends in ridership during the 1990s. ${ }^{4}$ From the entire sample of 587 reporting transit agencies, 227 agencies (or $62 \%$ of the sample) submitted complete data for some form of fixed-route transit service ${ }^{5}$ and increased ridership (measured as unlinked trips) during a four-year period between 1994-1995 and 1998-1999, a period in which transit ridership nationwide increased by 14 percent. ${ }^{6,7}$ These 227 agencies carried more than 86 percent of the total unlinked trips reported to the FTA in 1999.

Next, a questionnaire was developed and mailed a questionnaire to the chief executive of each of the 227 agencies. The questions were structured to allow respondents to address key factors contributing to their effectiveness in increasing ridership. The survey consisted of a combination of closed-ended, open-ended, and ranking questions; the questions sought information about the costs and benefits of programs and policies that contributed to ridership gains, the transit system's goals in increasing ridership, and how the ridership increase has benefited the community and the transit system. ${ }^{8}$ Findings from the literature review were used to 
develop the list of programs and policies. In addition, the survey asked respondents to discuss their respective agencies' future plans for maintaining and increasing ridership.

Five surveys were returned undeliverable, and a second attempt was made to contact these agencies to obtain valid contact information. Follow-up calls were placed to a random sample of 60 agencies that did not respond to the initial survey. Five agencies that responded to the mailed survey indicated their ridership levels actually decreased during the period of this study (in other words, the NTD data were incorrect). These agencies were subsequently removed from the sample. In total, 103 surveys were returned, for a response rate of 45 percent.

There are some limitations to the data and findings. We would expect that transit officials are more likely to attribute their ridership growths to internally controllable programs than to external factors outside of their immediate control. In this sense, it is important to view the questionnaire results more as the perceptions of experts and less as causal explanations of noteworthy ridership increases. In addition, because the survey was sent to only one person in each agency, responses may be biased to the individual's perception of the effectiveness of particular programs and factors, rather than representative of the agency-wide perspective of ridership increases. Finally, since surveys were conducted only of transit agencies that added riders in the late 1990s, the results do not reflect the views of transit managers whose systems lost riders during this period.

\section{Survey Findings and Analysis}

The internal and external factors thought by transit officials to influence ridership are summarized in Table 1. These internal and external factors, however, can be highly interdependent. For example, although many agencies attribute increased ridership to service expansions and the introduction of new and specialized programs, these services are often dependent on demand. In fact, many agencies report that an obstacle to increasing ridership even further is the lack of funds for more rolling stock and operating costs to meet demand. Nevertheless, throughout this study, external and internal factors are considered separately for purposes of analysis and presentation.

\section{Internal Factors}

Survey respondents indicated that in recent years, policy-makers have sharpened their focus on increasing public transit ridership, due in part to legislation such as the Clean Air Act Amendments of 1990 and the Transportation Equity Act for the 
Table 1. Iternal and External Factors Contributing to Ridership Growth

\begin{tabular}{|c|c|c|}
\hline \multirow{5}{*}{$\bar{E}$} & Fare Changes and Innovations & $\begin{array}{l}\text { Fare decrease or freeze } \\
\text { Universal fare coverage programs } \\
\text { Introduction of new payment options }\end{array}$ \\
\hline & Marketing and Information Programs & $\begin{array}{l}\text { Advertising } \\
\text { Niche marketing/marketing segmentation } \\
\text { Survey research } \\
\text { Customer satisfaction feedback mechanisms }\end{array}$ \\
\hline & Service Improvements & $\begin{array}{l}\text { Expansion of routes (geographic/temporal) } \\
\text { Introduction of new/specialized service } \\
\text { Route restructuring }\end{array}$ \\
\hline & Amenities/Service Quality & $\begin{array}{l}\text { Development of transit centers } \\
\text { Development of park-and-ride facilities } \\
\text { Increasing reliability of service } \\
\text { Cleanliness of vehicles } \\
\text { New equipment/rolling stock } \\
\text { Bus stop improvements (signage, shelters, benches) }\end{array}$ \\
\hline & Partnerships & $\begin{array}{l}\text { Community outreach/education } \\
\text { Planning and strategies } \\
\text { Intra-agency collaboration }\end{array}$ \\
\hline \multirow{4}{*}{ 跕 } & Population Growth & $\begin{array}{l}\text { More immigration } \\
\text { Rising transit dependency (aging populations, etc.) }\end{array}$ \\
\hline & Economy and Employment Growth & $\begin{array}{l}\text { Increased tourism } \\
\text { More demand for travel }\end{array}$ \\
\hline & Changing Metropolitan Form & $\begin{array}{l}\text { Suburbanization } \\
\text { Residential and employment relocation }\end{array}$ \\
\hline & Changes to Transportation System & $\begin{array}{l}\text { Increased congestion } \\
\text { Parking shortage and increasing costs } \\
\text { Rising gas prices } \\
\text { Construction proiects and time delavs }\end{array}$ \\
\hline
\end{tabular}

21st Century. Questionnaire results concerning the operating changes that transit officials believe have helped increase ridership can be grouped into five general types shown in Table $2 .^{9}$ These groups are:

1. transit service improvements through route expansion, restructuring, and new or specialized services,

2. fare innovations and changes,

3. marketing and informational efforts,

4. partnerships and community collaborations, and

5. improvements to service quality and passenger amenities.

Many transit systems report carrying out initiatives in several categories simultaneously. 
For each item, Table 2 notes the number of transit systems per size category-(1) very small, less than 1 million unlinked trips, (2) small, between 1 and 2 million trips, (3) medium, between 2 and 5 million trips, (4) large, between 5 and 20 million trips, and (5) very large, more than 20 million trips-responding that the item helped increase ridership. Each of the types of programs is discussed in turn below.

Service Improvements. Transit systems have undertaken a wide array of service improvements that have resulted in ridership gains. Service changes are defined here as any changes that alter the type or quantity of transit service as perceived by the riding public. These can include service expansions, introduction of new or specialized services, and route restructuring.

Table 2. Frequency of Reported Internal Factors

Contributing to Ridership Growth

\begin{tabular}{|c|c|c|c|c|c|c|c|c|}
\hline Intemed Prograns & $\begin{array}{c}\text { Veny.Sindl } \\
(n=29) \\
(I)\end{array}$ & $\begin{array}{c}\text { Sindl } \\
(n=13) \\
{[2]}\end{array}$ & $\begin{array}{c}\text { Medizm } \\
(n=22) \\
|3|\end{array}$ & $\begin{array}{c}\text { lage } \\
(n=17) \\
(4)\end{array}$ & $\begin{array}{c}\text { Verylage } \\
(n=22) \\
{[S]}\end{array}$ & $\begin{array}{c}\text { Tord } \\
(n=103) \\
(6]-[1]+[2]+ \\
{[3]+(4)+[5]}\end{array}$ & $\begin{array}{c}\text { Average } \\
{[7]} \\
-16] / 103\end{array}$ & Rankb \\
\hline \multicolumn{9}{|l|}{ Sentice Improvements } \\
\hline Service Expansion & 2 & 13 & 17 & 14 & 16 & 83 & $81 \%$ & 1 \\
\hline Route Restnuturing & 19 & 12 & 11 & 12 & 8 & 62 & $60 \%$ & 2 \\
\hline Introdretion of New/Specialized Services & 14 & 10 & 10 & 6 & 11 & 51 & $50 \%$ & 4 \\
\hline \multicolumn{9}{|l|}{ Fare Imountions and Changes } \\
\hline New Payment Options & 7 & 5 & 2 & 8 & 7 & 29 & $28 \%$ & 6 \\
\hline Universal Fare Conerase Prograns (URC) & 2 & 6 & 6 & 5 & 9 & 28 & $27 \%$ & 7 \\
\hline Fare Freenes and Docreases & 12 & 1 & 1 & 2 & 4 & 20 & $19 \%$ & 9 \\
\hline \multicolumn{9}{|l|}{ Marketing } \\
\hline Adhertising/Irformation Programs & 20 & 9 & 12 & 7 & 11 & 59 & $57 \%$ & 3 \\
\hline Market SegnentationNiche Marbeting & 2 & $\mathbf{0}$ & o & 6 & 2 & 10 & $10 \%$ & 10 \\
\hline \multicolumn{9}{|l|}{ Parenerships and Commerity Collabonations } \\
\hline Emploser-bosed Parnerships (incl. URC) & 3 & 7 & 6 & 9 & 8 & 33 & $32 \%$ & 5 \\
\hline University basod Partnastips (incl. UFC) & 3 & 4 & 7 & 5 & 6 & 25 & $24 \%$ & 8 \\
\hline Commenity Ourreach and Local Covernment & 2 & 0 & 3 & 2 & $\mathbf{0}$ & 7 & $7 \%$ & 11 \\
\hline Socisl Services Collaborations & 1 & 1 & $\mathbf{0}$ & 1 & 2 & 5 & $5 \%$ & 14 \\
\hline \multicolumn{9}{|l|}{ Senvice Qualiy and Amentities } \\
\hline Inproved Schoctule/Service Reliability & 1 & $\mathbf{0}$ & 2 & 3 & 1 & 7 & $7 \%$ & 11 \\
\hline Park-and-Ride Lots & 1 & 2 & 1 & 0 & 2 & 6 & $6 \%$ & 13 \\
\hline Rail Development & o & l & $\mathbf{0}$ & $\mathbf{0}$ & 4 & 3 & $5 \%$ & 14 \\
\hline Trensit Center Inprovements & 1 & 0 & $\mathbf{I}$ & 1 & 0 & 3 & $3 \%$ & 16 \\
\hline Sufety, Clearliness & 0 & $\mathbf{0}$ & $\mathbf{0}$ & 3 & $\mathbf{0}$ & 3 & $3 \%$ & 16 \\
\hline New Buses & 1 & $\mathbf{0}$ & o & $\mathbf{0}$ & 1 & 2 & $2 \%$ & 18 \\
\hline \multicolumn{9}{|c|}{ 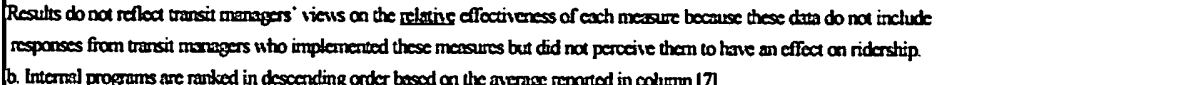 } \\
\hline
\end{tabular}




\section{Table 3. Reported Transit Service Improvements Contributing to Ridership Growth}

\begin{tabular}{|c|c|c|c|}
\hline & Agency Name & Effectiveness & Ispe of Expanston \\
\hline Very Smell & 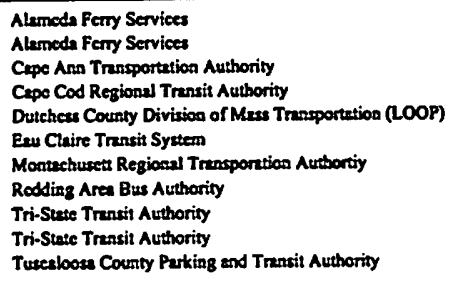 & $\begin{array}{l}\text { Very effective } \\
\text { Very effectivo } \\
\text { Did not specify } \\
\text { Did not specify } \\
\text { Did not apecify } \\
\text { Somewtal effective } \\
\text { Somewhut effoctive } \\
\text { Did not ppecify } \\
\text { Very effective } \\
\text { Very effective } \\
\text { Did not qpecify }\end{array}$ & 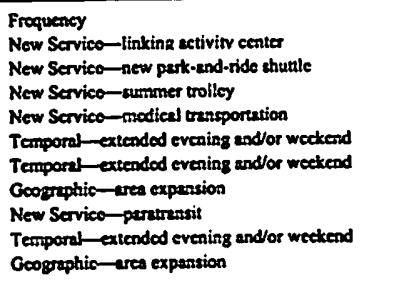 \\
\hline Small & $\begin{array}{l}\text { Leketand Area Transit Dietriet } \\
\text { Lakeland Area Transit Distriet } \\
\text { Sonoma County Transis }\end{array}$ & $\begin{array}{l}\text { Somewhat effective } \\
\text { Somewhet effective } \\
\text { Somewhat effective }\end{array}$ & $\begin{array}{l}\text { Goographic-area expansion } \\
\text { Restructure Routca-better transfen } \\
\text { New Servico-renior roules end expandod peratransil }\end{array}$ \\
\hline Mediun & 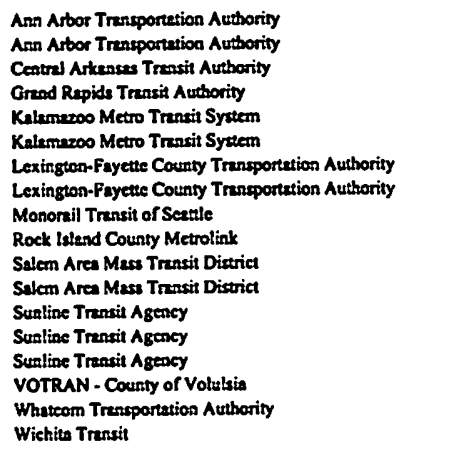 & 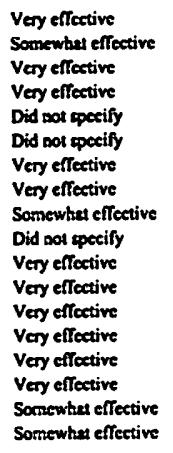 & 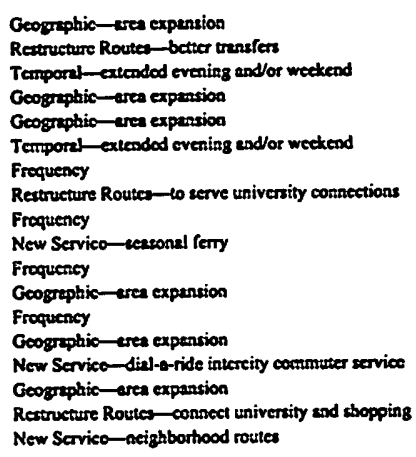 \\
\hline Large & 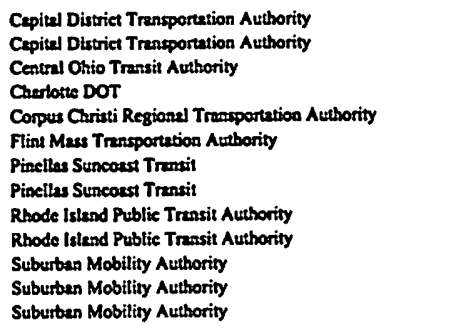 & 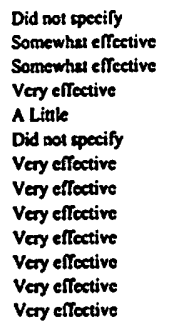 & 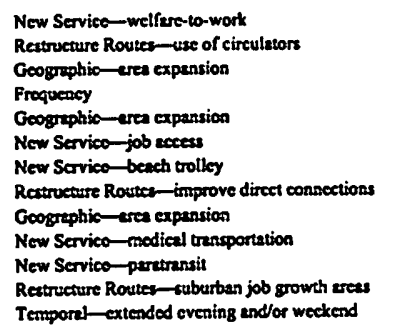 \\
\hline Vary lase & 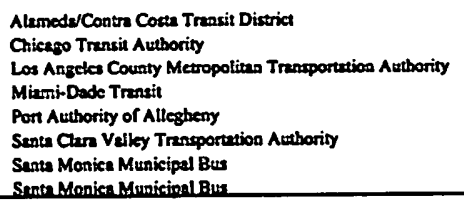 & 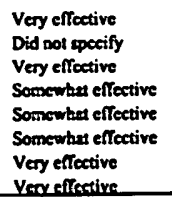 & 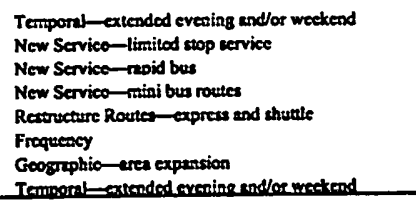 \\
\hline
\end{tabular}


Service Expansion. Service expansions mentioned by respondents include programs that increase service hours, provide additional or extended evening and/ or weekend service, and expand the geographic coverage area through new routes. At least 73 percent of transit systems in all size categories, and 81 percent of all agencies, reported that service expansions and changes contributed to ridership increases (Table 2).

Introduction of New/Specialized Services. Agencies also reported that the introduction of new services targeted to populations with specialized needs (e.g., welfare-to-work recipients, tourists, the disabled, and senior citizens) helped increase ridership. Fifty percent of all responding transit systems, ranging from 35 percent of large systems to 77 percent of small systems, report that new and specialized services contributed to their ridership increase (Table 2). Some service changes were implemented in response to changing urban form and travel patterns; for example, the Sunline Transit Agency (CA) introduced intercity commuter services to meet growing suburbanization and increasing travel distances.

Route Restructuring. Most of the route restructuring reported by transit systems involved service modifications (e.g., redesigning routes for efficiency, simplifying routes for user-friendliness, eliminating unproductive service, redirecting obsolete service, eliminating deviations, coordinating radial/grid routes, creating tiered systems of transit, and focusing service on major corridors and activity centers). Above all, transit officials report that they attempt to structure services to better match an increasing variety of travel needs within diverse markets. These special needs include commuter travel from suburb-tosuburb, seasonal tourism, welfare-to-work transportation, and medical transportation programs. For example, the Redding (CA) Area Bus Authority reports that improved service and broader coverage has diversified mode choice options for many trips.

Table 3 identifies agencies that specifically cited particular types of service improvements-either through expanded geographic coverage area, temporal expansion of service (i.e., new evening and/or weekend service), route restructuring, or the introduction of specialized services - with the reported degree to which respondents attribute ridership increases to service improvements.

Fare Innovations and Changes. Fare and pricing adaptations that change the fare level, fare media, or payment options alter the price of transit service rela- 
tive to its quality and convenience. Types of fare adjustments mentioned by respondents include changes in base fares, passes and discounting strategies, changes to transfer policies that effectively lowered fares, and partnerships with businesses or other organizations or institutions to provide discounts or universal fare coverage.

Fare Decreases and Freezes. Nineteen percent of all responding transit systems, ranging from less than 5 percent of medium systems to 41 percent of very small systems, report that a fare decrease helped increase their ridership (Table 2). Some transit agencies use deep discount pricing strategies by offering a per ride discount with the purchase of multiple rides, which increases ridership without losing much fare revenue (Oram 1990). In addition, some transit systems have kept cash fares the same for many consecutive years in the face of inflation, which is a de facto fare decrease. For example, the Cape Ann (MA) Transportation Authority kept its shuttle fares at $\$ 0.25$ and $\$ 0.50$, and reports that the low fares have helped increase ridership over time. Similarly, the Orange County (CA) Transportation Authority, which has not instituted a fare hike in nine years, reports that its ridership growth may be due in part to steady fares.

Special fare promotions and "free fare" events, however, have been used to a lesser extent to increase ridership. Ben Franklin Transit (WA) experimented with fare-free local routes on Wednesdays and Saturdays. The agency found that the free days introduced new riders to the system, thus increasing ridership on regular fare days. Although the agency reports reduced revenue from the free service, the loss was minimal since fares were only $\$ 0.40$ to $\$ 0.50$.

New Payment Options. Technological advances in recent years have brought stored value card technology to transit, and in some cases transit cards can be used on more than one transit system. Twenty-eight percent of all responding transit systems, ranging from 9 percent of medium systems to 47 percent of large systems, report that new payment options helped increase their ridership (Table 2). Omnitrans (CA) reports that it has equipped buses in Riverside with new add-on farebox units for handling the new technology, offering passengers a choice among a variety of fare media at minimum operations costs. Rhode Island Public Transit Authority (RIPTA) also has created one-day and family passes that are targeted to tourists. Other agencies, such as Bay Area Rapid Transit (BART) and Sonoma County Transit (both in California) have 
also provided pass sales over the Internet and credit card and debit card payment options at stations. Many of the respondents believe that the new flexibility in fare payment has helped increase ridership, although its degree of effectiveness is relatively small when compared with fare media changes. Most agencies that reported fare media changes-generally discounted passes or ride cards that also lowered fares for frequent riders-reported a greater degree of effectiveness in increasing ridership.

\section{Table 4. Reported Fare Restructuring Contributing to Ridership Growth}

\begin{tabular}{|c|c|c|c|}
\hline & Agray Name & Fifectineness & Tipe of thoxgmor Charge \\
\hline Verysindl & 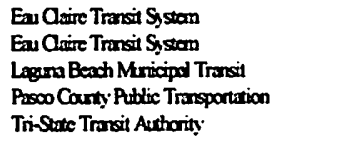 & 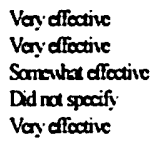 & 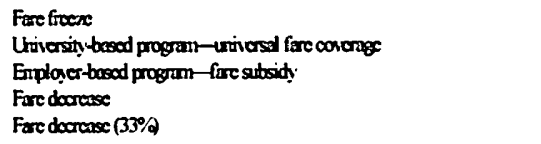 \\
\hline Sinall & 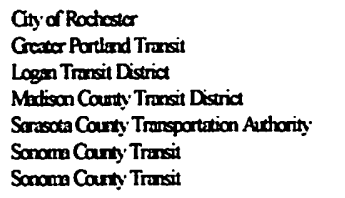 & 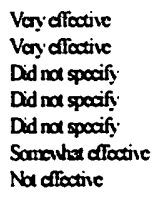 & 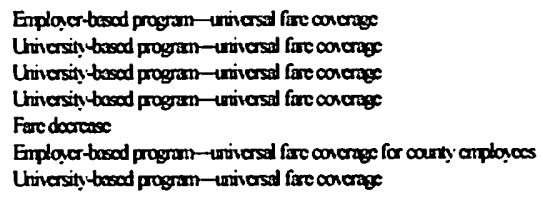 \\
\hline Mexion & 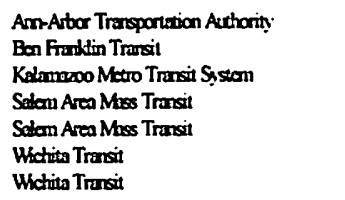 & 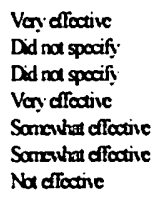 & 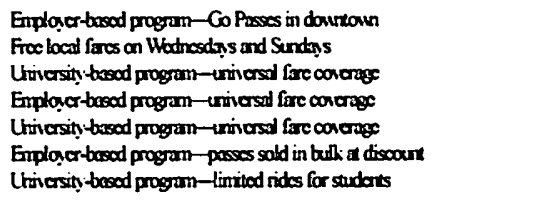 \\
\hline Lorge & 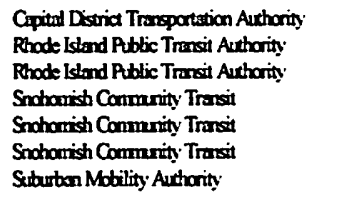 & 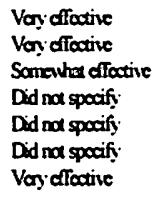 & 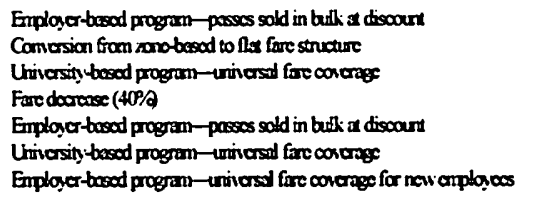 \\
\hline Verylary & 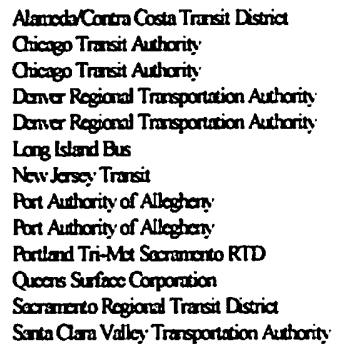 & 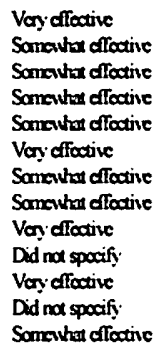 & 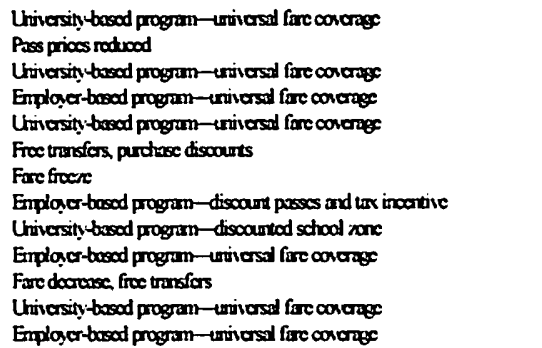 \\
\hline
\end{tabular}


Table 5. Reported Marketing Programs Contributing to Ridership Growth

\begin{tabular}{|c|c|c|c|}
\hline & Asonay Noms & Effectivenoss & Jppe of Progrem \\
\hline Vens Sindl & 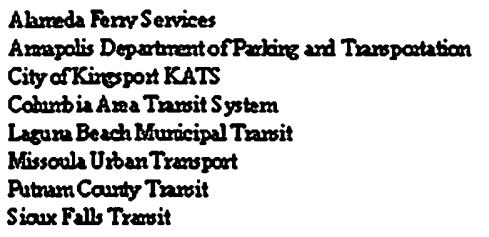 & $\begin{array}{l}\text { Verveffective } \\
\text { Did motspecify } \\
\text { Did motspecify } \\
\text { Somewhat effective } \\
\text { Somewhateffective } \\
\text { Vexy offective } \\
\text { Somernatefiective } \\
\text { Vexy effoctive }\end{array}$ & 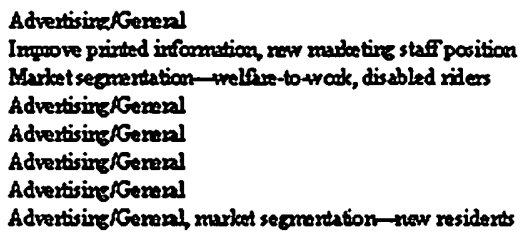 \\
\hline Small & 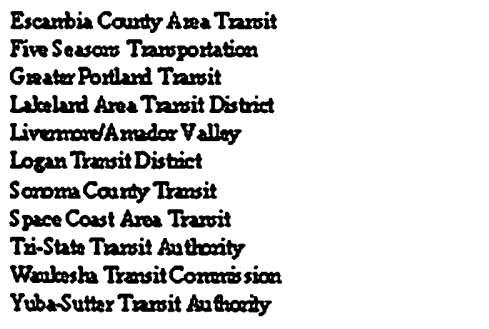 & 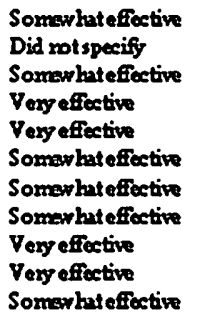 & 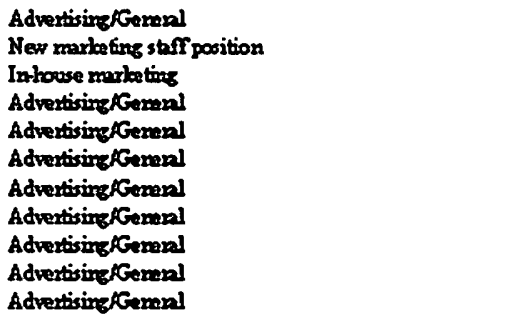 \\
\hline Medium & 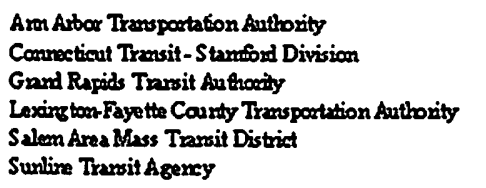 & $\begin{array}{l}\text { Somerhat effective } \\
\text { Somowhat effective } \\
\text { Somavhat effective } \\
\text { Very effective } \\
\text { Very effective } \\
\text { Somewhat effective }\end{array}$ & 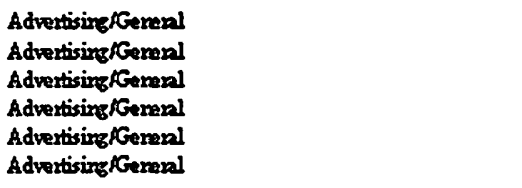 \\
\hline
\end{tabular}


Table 5. Reported Marketing Programs Contributing to Ridership Growth (cont.)

\begin{tabular}{|c|c|c|c|}
\hline & Agonay Noms & Effocriveress & Inpe of Progem \\
\hline Larg: & 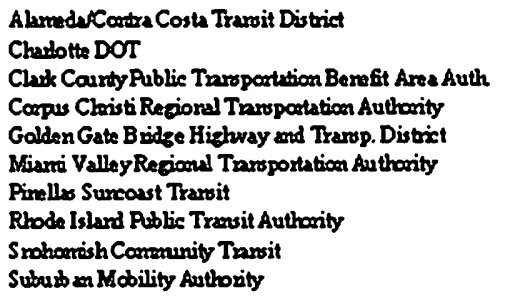 & $\begin{array}{l}\text { Somewhat effective } \\
\text { Vexy effective } \\
\text { Did rot specify } \\
\text { Somewhat efective } \\
\text { Somewhat effective } \\
\text { Somewhateffective } \\
\text { Very effective } \\
\text { Very effective } \\
\text { Did not specify } \\
\text { Very effective }\end{array}$ & 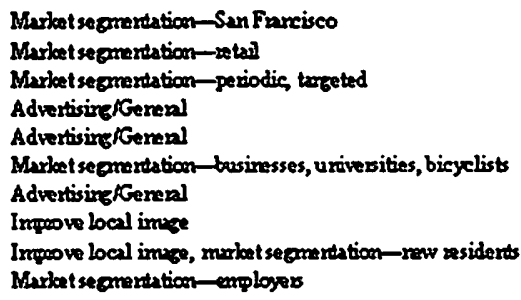 \\
\hline Vor Lage & 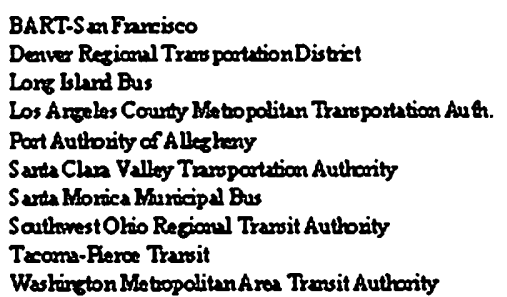 & $\begin{array}{l}\text { Somewhat efective } \\
\text { Somewhal efective } \\
\text { Somewhat efective } \\
\text { Somewhat efective } \\
\text { Somewhat efrective } \\
\text { Somewhat effective } \\
\text { Somewhat effective } \\
\text { Very effective } \\
\text { Very effoctive } \\
\text { Somewhat efoctive }\end{array}$ & 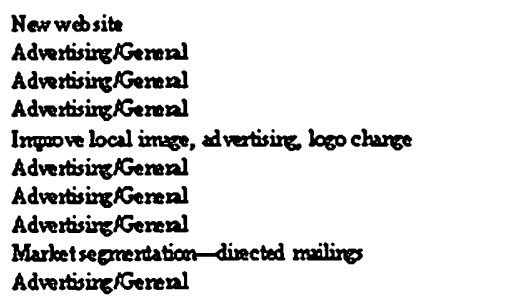 \\
\hline
\end{tabular}


Universal Fare Coverage Programs. In combining fare discounts and the innovation of new fare media and payment options, some agencies have implemented universal fare coverage programs in partnerships with local agencies, businesses, or institutions. In a universal fare coverage program, local public transit systems provide fare-free transit service for all members of a particular community, such as employees of a business or students of a local university or school. ${ }^{10}$ The partnering agency or institution typically pays the transit agency an annual lump sum based on expected ridership, and riders show their business or school identification to receive either free or heavily discounted transit rides. Table 4 summarizes the types of fare programs or changes that agencies reported and the degree to which the respondents believe they have affected increased ridership.

Fifteen agencies attributed ridership increases to university-based fare programs, of which 13 agencies reported that the programs significantly helped increase ridership. Thirteen agencies surveyed reported that partnerships with businesses-either employer subsidized passes or universal fare coveragehelped increase ridership levels. The City of Rochester ( $M N)$, Ann Arbor Transportation Authority (MI), Salem Area Mass Transit (OR), Capital District Transportation Authority (NY), and Suburban Mobility Authority (MI) all reported that such programs were highly effective in increasing ridership.

Marketing. New marketing strategies include general information programs and programs targeted at specific riders or specific services. Marketing strategies increase the level of information about transit services without actual changes to the services themselves. Table 5 summarizes the types of marketing programs or efforts that agencies reported and the degree to which the respondents believe they have increased ridership.

Advertising and Information Programs. In all size categories, more than half of the respondents made reference to marketing initiatives as major factors. Fifty-seven percent of all responding transit systems, ranging from 41 percent of large systems to 69 percent of very small and small systems, report that general marketing and advertising campaigns helped increase their ridership (Table 2).

Market Segmentation and Niche Marketing. Transit agencies have pursued innovative marketing techniques aimed at certain submarkets. Market segmentation, widely used throughout the transit industry, is the practice of identifying groups of people who have similar characteristics or needs and who are 
likely to exhibit similar purchase behavior and/or responses to changes in the marketing mix (Elmore-Yalch 1998). Ten percent of all responding transit systems report that market segmentation defined by geographic area, trip purpose, or socioeconomic characteristics helped increase ridership (Table 2). For example, Kingsport (TN) Area Transit Service targets markets that are most likely to rely on transit service: welfare recipients, low-income workers, and disabled citizens. Chicago (IL) Metra emphasizes niche marketing to off-peak and discretionary, reverse commute, and suburb-to-suburb riders, to broaden their market beyond traditional downtown riders.

Partnerships and Community Collaborations. When transit systems coordinate services with businesses, organizations, or institutions, they attempt to address the needs of a specific market on a unique basis. In particular, transit

\section{Table 6. Reported Partnerships (Excluding Fare Programs) Contributing to Ridership Growth}

\begin{tabular}{|c|c|c|}
\hline & Agexcy $\mathrm{Nam}$ & Nenoe of Colldoration \\
\hline VerySindl & 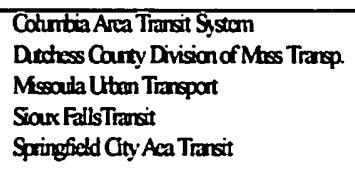 & 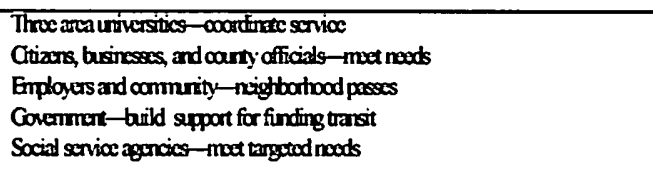 \\
\hline Sindl & $\begin{array}{l}\text { Oty of Visadia - Visalia Cty Conch } \\
\text { FiveScasons Traspotation } \\
\text { Grater Portand Transit } \\
\text { Lakedand Arn Transit District }\end{array}$ & 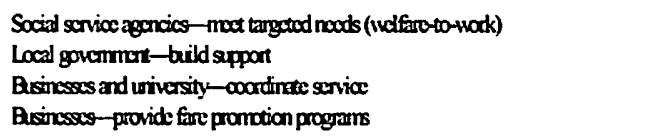 \\
\hline Mexiom & 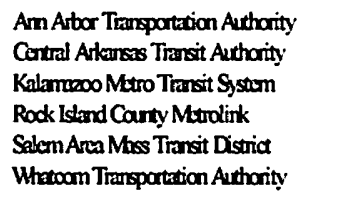 & 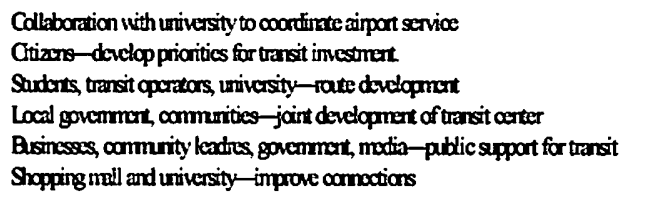 \\
\hline Lorgy & 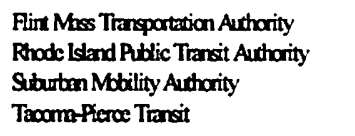 & 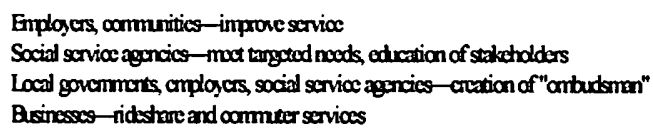 \\
\hline Verylarge & Denner Rogional Traspotation Distria & Businesses-moct comploycr noods \\
\hline
\end{tabular}


systems in recent years have begun to enter into partnership with colleges and universities, employers, housing developers, and social service agencies and clients. In addition to universal fare coverage mentioned previously, transit systems report that they have increased ridership because they reach a wider range of citizens by adding new service or tailoring existing service to the riding patterns of specifically targeted groups. Table 6 presents collaborative programs reported by respondents."

Employer-based Partnerships. Several agencies reported that they work in cooperation with local businesses to provide service to employees, reduce parking pressures on businesses, and encourage a higher transit mode split. Thirty-two percent of all agencies, ranging from 10 percent of very small systems to 54 percent of small systems, reported some interaction or collaboration with the local business community such as universal fare coverage programs, information programs, or service planning. For example, RIPTA, Chicago (IL) Transit Authority, and Tacoma-Pierce (WA) Transit have partnered with local businesses to provide commuter benefit and rideshare programs.

University-based Partnerships. Rosenbloom (1998) and Brown et al. (2001) find that university-based transit programs are among transit's key success stories in the United States. Twenty-five transit systems (or $24 \%$ of transit systems responding to the questionnaire) report that coordination with colleges and universities in their service area helped increase ridership by gearing transit service toward the university community. Ten percent of the very small, 31 percent of small, 32 percent of medium, 29 percent of large, and 27 percent of very large agencies reported working with universities to better serve travel needs and thus increase ridership.

Community Outreach and Local Government. Seven percent of the agencies reported that support from citizens and local governments has been critical in implementing service to attract riders. Through community meetings and local government support, agencies are better able to address public needs, build support and consensus, and develop community objectives and priorities. Most important, these outcomes led to an increased likelihood for funding. For instance, Sioux Falls (SD) Transit reported that its city government strongly supported transit, and this has ensured funding and facilitated marketing. 
Social Services Collaborations. Five percent of all responding transit systems also report that partnerships established with human and social service agencies have helped boost ridership (Table 2). Transit systems are assessing how public transit can address the needs of the potential market. Three transit systems report that their coordination with welfare-to-work programs has helped increase ridership: Kingsport (TN) Area Transit Service (KATS), Visalia City (CA) Coach, and Five Seasons Transportation (Cedar Raids, IA). Usually the county

Table 7. Reported Service Quality and Amenities Contributing to Ridership Growth

\begin{tabular}{|c|c|c|}
\hline & Agency Name & Type of Amenity \\
\hline Very Small & $\begin{array}{l}\text { Cope Ann Trensportation Authority } \\
\text { Sioux Falls Transit } \\
\text { Space Coast Area Transit }\end{array}$ & $\begin{array}{l}\text { Part-end-Ride lots/shutties } \\
\text { New buses } \\
\text { Bus stop amenities }\end{array}$ \\
\hline Sonall & $\begin{array}{l}\text { City of Rochester } \\
\text { Greater Roanoke Transit } \\
\text { Livermore/Armador Valley }\end{array}$ & $\begin{array}{l}\text { Park-and-ride lots/shutties } \\
\text { Park-and-ride lots/shuttles } \\
\text { Rail development }\end{array}$ \\
\hline Medium & $\begin{array}{l}\text { Ann Arbor Transportation Authority } \\
\text { Lexington-Fayette County Transportation Authority } \\
\text { Rock Island MetroLink } \\
\text { Salem Area Mass Transit }\end{array}$ & $\begin{array}{l}\text { Park-and-ride lots/shuttles } \\
\text { Bus stop amenities } \\
\text { Transit center } \\
\text { Park-and-ride lots/shuttles }\end{array}$ \\
\hline Lange & $\begin{array}{l}\text { Fresno Area Express } \\
\text { Fresno Area Express } \\
\text { Montebello Bus Lines } \\
\text { Montebello Bus Lines } \\
\text { Pinellas Suncoast Transit } \\
\text { Pinellas Suncoast Transit } \\
\text { Rhode Island Public Transit Authority } \\
\text { Rhode Island Public Transit Authority }\end{array}$ & $\begin{array}{l}\text { Safety, cleanliness } \\
\text { Reliability } \\
\text { Safety, cleanliness } \\
\text { Reliability } \\
\text { Bus stop amenities } \\
\text { New buses } \\
\text { Safety, cleanliness } \\
\text { Reliability }\end{array}$ \\
\hline Very Large & $\begin{array}{l}\text { Chicago-RTA-Metra } \\
\text { Denver Regional Transportation Authority } \\
\text { Los Angeles County MTA } \\
\text { Massechusetts Bay Transportation Authority } \\
\text { Queens Surface Corporation } \\
\text { San Juan MTA } \\
\text { Southwest Ohio Regional Transit Authority } \\
\text { Washington Metro Area Transit Authority }\end{array}$ & $\begin{array}{l}\text { Park-and-ride lots/shuttles } \\
\text { Rail development } \\
\text { Rail development } \\
\text { Rail development } \\
\text { New buses } \\
\text { Reliability } \\
\text { Park-and-ride lots/shuutles } \\
\text { Rail development }\end{array}$ \\
\hline
\end{tabular}


department of welfare purchases transit passes from the transit system for eligible clients to facilitate travel to social service agencies, job training centers, and potential employment locations that are dispersed across a wide geographic area.

Some transit systems have been successful in converting a large number of taxi and medical transportation passengers to public transit. In Poughkeepsie (NY), the Dutchess County Mass Transit acquired responsibilities for the County Medicaid Transportation program. In addition, some systems report modifying and expanding bus routes to meet the needs of the traveling public. KATS also reports that it serves a large number of disabled passengers; when the City eliminated its taxi subsidy program, many passengers shifted to transit.

Service Quality and Amenities. Many of the survey respondents mentioned the importance of improvements or enhancements to the quality and reliability of current or new transit services. Apart from service modifications, some transit systems have made service quality improvements that have helped increase ridership. Twenty-five percent of all responding transit systems report that passenger amenities and other quality improvements that enhance the experience of riding transit helped increase ridership (Table 2). These service quality and amenity improvements include reducing headways; increasing service frequencies; improving service reliability; adding bus shelters, benches, signage at bus stops, and park-and-ride lots at rail stations; and improving safety and cleanliness. Table 7 summarizes the amenity improvements reported. ${ }^{12}$

Park-and-Ride Lots. Several transit systems report that they have coordinated transit services with parking. Five Seasons Transportation has assumed management of downtown parking in Cedar Rapids (IA) and subsidizes citywide transit with downtown parking revenue. Other systems operate suburban parkand-ride facilities. Chicago's Metra, Salem (OR) Area Mass Transit District, Southwest Ohio Regional Transit Authority, Ann Arbor Transportation Authority, Greater Roanoke (VA) Transit, Cape Ann (MA) Transportation Authority, and City of Rochester (MN) maintain park-and-ride lots and attribute ridership growth, in part, to commuters.

Rail Development. Five agencies report that rail projects have been helpful in increasing ridership during the late 1990s. Livermore/Amador Valley (CA) attributes 20 percent of its ridership growth to BART's extension into its service 
area. The Los Angeles County (CA) MTA and Washington (DC) Metropolitan Area Transit Authority both report that expanded rail routes and services were a major factor contributing to the ridership increases. Denver (CO) Regional Transportation District also attributes ridership growth to a new light rail line serving suburban commuters. The agency reports that future plans include further light rail development and the linking of buses into the rail configuration. Boston's MBTA reports that commuter rail expansion has heavily contributed to ridership growth by increasing capacity and improving the reliability of the transit system.

While rail development may increase system capacity and attract new riders, it may also increase the number of transfers needed to complete a journey and thus increase the number of unlinked passenger trips, but not the total number of linked trips.

Transit Center Improvements. A few respondents reported that their agencies had created or were in the process of developing new intermodal transit centers to help coordinate and improve transfers among transportation modes. These centers provide rider-friendly environments and amenities for waiting passengers. Rock Island (IL) Metrolink completed a new $\$ 8$ million transfer center in 1998 as a joint development project between a municipality and a private development company. The transfer center was an integral part of a large downtown redevelopment program, and the transit system was a significant partner in economic development. According to the agency, the transit center allows more convenient and secure transfer between routes and provides greater mobility for residents.

Space Coast (FL)Area Transit and Pinellas (FL) Suncoast Transit and LexingtonFayette County (KY) Transportation Authority reported improving and providing bus stop signage and information, shelters, or seating.

As with rail development, some of the increase in unlinked passenger trips associated with restructuring bus routes around transfer centers may be due to an increase in the number of transfers, but not necessarily to an increase in the number of linked passenger trips.

Safety, Cleanliness, Reliability, and Shortened Headways. Several agencies such as Fresno Area Express and Montebello Bus Lines (both in California) and Regional Public Transportation Authority (AZ) reported that safety and cleanliness were important factors in attracting riders by changing perceptions about 
transit and increasing the comfort of the rides.Efforts to increase service reliability were also important in attracting riders and included shortening headways, increasing schedule adherence, and reducing wait times. San Juan (PR) Metropolitan Bus Authority aggressively works to comply with schedules and attributes ridership growth to their increasingly dependable service.

New Buses. While agencies often mentioned bus procurement as a factor in providing increased service, a few agencies specifically named acquiring new buses as a way to improve passenger comfort and convenience. Some respondents claim that the acquisition of new handicap-accessible, low-floor buses has been instrumental in attracting specific populations as well as increasing the reliability of the fleet for more dependable service.

Among the many internal factors identified by survey respondents, service improvements, such as service expansion, route restructuring, and introduction of new/specialized services, are the most frequently reported (Table 2 ). And service improvements were also most frequently cited by respondents as having positive effects on ridership (Table 3). Following service improvements, advertising/information programs were mentioned by more than half of the respondents. Views on the effectiveness of these programs were mixed, however; the managers of smaller transit systems were more likely than their counterparts in large transit systems to believe that advertising and information programs helped to increase patronage (Table 5). As noted in the literature review, few agencies implement fare freezes or reductions in an effort to increase ridership (Table 2), and respondents to the survey reported here were generally skeptical of their effectiveness, even managers of systems that implemented fare freezes or reductions (Table 5). In contrast to acrossthe-board fare reductions, two fare innovations-new payment options and universal fare coverage programs-were frequently cited as having significant effects on patronage (Table 5). Lastly, two forms of institutional partnering-employerbased and university-based - are cited by one-third and one-fourth of respondents, respectively (Table 2), as having significant effects on ridership growth (Table 6).Because many of the statistical analyses of transit ridership have found that external factors-those outside of the control of transit managers - have significant effects on changes in transit ridership, transit managers' perceptions of the importance of these factors are explicity analyzed in the following section. 
Table 8. Frequency of Reported External Factors Contributing to Ridership Growth

\begin{tabular}{|c|c|c|c|c|c|c|c|}
\hline & $\begin{array}{c}\text { Very Small } \\
(n=29) \\
{[I]}\end{array}$ & $\begin{array}{c}\text { Small } \\
(n=13) \\
{[2]}\end{array}$ & $\begin{array}{c}\text { Medium } \\
(n=22) \\
{[3]}\end{array}$ & $\begin{array}{c}\text { Lorge } \\
(n=17) \\
{[4]}\end{array}$ & $\begin{array}{c}\text { Very Lange } \\
(n=22) \\
{[5]}\end{array}$ & $\begin{array}{c}\text { Total } \\
(n=103) \\
6]=[1]+[2]+[3]+[4]+[5,\end{array}$ & $\begin{array}{l}\text { Average } \\
{[6] / 103}\end{array}$ \\
\hline Population Growth & 6 & 3 & 6 & 6 & 7 & 28 & $27 \%$ \\
\hline Strong Economy/Employment & 1 & 0 & 1 & 0 & 13 & 15 & $15 \%$ \\
\hline More Congestion & 0 & 0 & 2 & 3 & 2 & 11 & $11 \%$ \\
\hline Increased Immigration/Transit Dependency & 1 & 0 & 2 & 2 & 0 & 5 & $5 \%$ \\
\hline Suburbanization/New Residential and Employment Areas & 1 & 0 & 1 & 0 & 2 & 4 & $4 \%$ \\
\hline Parking Shortage/Costs and Gas & 0 & 0 & 1 & $\mathbf{0}$ & 3 & 4 & $4 \%$ \\
\hline \multicolumn{8}{|c|}{$\begin{array}{l}\text { Note: Multiple-responses, do not sum to } 100 \% \\
\text { a. Questionnaire results reflect perceptions of experts and not necessarily causal explanations of ridership increases. } \\
\text { Results do not reflect views of transit managers who implemented programs but found no significant ridership increase. }\end{array}$} \\
\hline
\end{tabular}




\section{External Factors}

External factors, outside the direct control of transit agencies, are less relevant to transit managers than internal factors, but nevertheless they are clearly important determinants of transit patronage. These external factors are subdivided into five categories: population growth, employment/economic growth, changing metropolitan form, and changes to the transportation system (Table 8).

Population Growth and Increased Immigration/Transit Dependency. Location in a rapidly growing metropolitan area contributes to the success of some transit systems. Regional population growth expands the pool of potential riders and usually results in more activity and more travel. High population growth was mentioned by survey respondents in all five agency-size categories and in all regions of the country. Some respondents identified particular growing population subgroups as important transit markets that have contributed to the growth in ridership. These subgroups include the Latino population for Santa Maria (CA) Area Transit and Annapolis (MD) Transit and senior citizens, many of whom are no longer able to drive automobiles, for the Pasco County (FL) Public Transportation Authority. Some agencies also target new residents moving into the service area to encourage transit use. Snohomish (WA) Community Transit and Sioux Falls (SD) Transit, for example, market to new residents in the area through targeted mailings or Welcome Wagon promotions.

Employment Growth. Since growth in employment generally accompanies growth in population, one can reasonably assume that accompanying employment growth also played a role in ridership increases. Previous research has found a relationship between system size and employment level. According to Kain and Liu (1996), "service miles supplied is a policy variable highly correlated with both employment and population in the service area." There are certain employment/worker subgroups that respondents have identified as contributing to their overall ridership increase. For example, the Jackson (TN) Transit Authority reports that large employment growth among part-time fastfood workers, who typically depend on transit for their commute to work, helped to increase ridership. ${ }^{13}$ In addition, local governments in some rapidly growing areas have partnered with transit agencies to increase and integrate transit service to attract businesses and light industrial companies to locate in the area. 
Economic Growth. During the early 1990s, aggregate transit ridership nationwide was declining slightly, coinciding with lagging economic performance nationally. After the economic recession of 1989-1993 abated, the late 1990s were marked by a sustained period of economic growth nationwide. Some transit officials report that, with a healthy economy, more people are working, have more money to spend, and tend to travel more. For example, the Orange County (CA) Transportation Authority reports that an improved local economy in recent years has helped increase its ridership. Meanwhile, other transit officials report that transit ridership fell during the period of economic growth, concluding that the robust economy improved incomes and increased levels of automobile ownership, which led to increased auto travel and decreased transit use.

Some respondents report that their transit systems have begun to pay more attention to visitor and tourism demands. The Cape Cod (MA) Regional Transit Authority notes that an expanding tourist industry has helped increase its ridership. Transit systems also can make transit travel attractive to tourists through route design and payment options. As mentioned earlier, some agencies have created pass programs and specialized services to serve tourist and visitor needs. These include Escambia County (FL) Area Transit's beach trolleys and Rock Island County (IL) Metrolink's seasonal ferries. Seasonal peaking, however, may be difficult to manage in the long term because it does not efficiently use capital and labor throughout the year.

Changing Metropolitan Form. Many academics and researchers have attributed transit's decline in the United States to the suburbanization of jobs and households (Fielding 1995). Low-density suburban neighborhoods separate homes both from each other and from commercial establishments. Decentralized job sites and residences are difficult to serve by traditional public transit because transit works best when a large number of people are all headed to activity nodes that contain various destinations. Dense and compact sites are more conducive to efficient transit operations than dispersed and sprawling patterns of urban development. For suburban transit systems, however, growing suburbs mean more riders. While sprawling homes and worksites are blamed by many for decreasing transit use, the respondent from the Sacramento (CA) Regional Transit District reports that a state policy of locating office buildings along transit lines (both bus and rail) has helped boost ridership. 


\section{Changes to the Transportation System (Congestion, Parking Shortage)} Costs, and Gas). Significant travel time and dollar savings can induce riders to switch from other modes to transit. Snohomish (WA) Community Transit reports that the addition of high-occupancy vehicle/bus lanes on the Interstate 5 corridor has helped boost its ridership by reducing the time costs of transit travel relative to single-occupancy driving. The transit system reports that its "commuter express" serves a well-defined commuter need and is an important market where transit can be competitive against the single-occupancy vehicle.

Changes to the price of traveling by automobile, which is transit's chief competitor, can affect people's mode choices. The Orange County (CA) Transportation Authority reports that the rising cost of owning an automobile (especially the cost of insurance and fuel) as well as stiff penalties for DWIs (driving while intoxicated) and driving without a license have helped increase ridership. In addition, 15 percent of all agencies pointed to increasing congestion and time costs of driving and believe that this disincentive to car use has given people an incentive to use transit. Other agencies, such as Whatcom (WA) Transportation Authority and Southwest Ohio Regional Transit Authority, reported that increasing parking costs, high demand for parking, and parking shortages have been influential factors in the agencies' abilities to attract riders.

Several agencies also reported that regional construction projects, though localized and temporary, have also helped to increase the viability and attractiveness of transit use. Washington (DC) Metropolitan Area Transit Authority's rail construction, Boston's MBTA's “Big Dig" highway/tunnel project, and highway and riverfront construction in the Southwest Ohio Regional Transit Authority's area are all examples cited of local and temporary disruptions to transportation systems that have shifted some drivers to transit.

It was expected that respondents to the survey would be more likely to cite internal factors and less likely to cite external factors in explaining transit ridership growth on their systems. And this was, indeed, the case, though external factors were cited more often than we might have guessed. Among the six factors reported, population growth, economic/employment growth, and worsening traffic congestion are considered by the respondents to have significantly affected ridership. Interestingly, respondents from medium-sized, large, and very large agencies were far more likely to cite external factors than their counterparts at smaller systems. 


\section{Conclusions}

This study conducted a national survey of transit agencies in the United States that added riders during the late 1990 s to identify what factors are considered by transit managers to have most significantly influenced recent ridership growth. Transit managers were asked about recent changes in their systems and what factorsboth internal and external-they believed to be most responsible for increasing ridership. Overall, service improvements were the most frequently cited factors. This is perhaps not surprising because (1) more frequent service and broader network coverage increases capacity to serve more riders, and (2) such service improvements often (though not always) occur in response to increasing demand. While survey respondents were collectively skeptical of the effects of across-theboard fare reductions on ridership, they were generally enthusiastic about the influence of universal fare coverage programs (combinations of fare discounts and new fare media and payment options). These universal fare coverage and partnership programs represent the efforts of transit systems to improve their flexibility and responsiveness in meeting mobility needs of particular market segments and changing demographics and development patterns. Although several previous studies of transit ridership have found that service quality improvements (such as more reliable service, cleaner vehicles, safer, more attractive stops) trump fare reductions in attracting riders, relatively few respondents attributed patronage growth to improvements in the quality of service.

As expected, the transit managers surveyed were more likely to cite internal factors to their systems as responsible for increasing ridership, rather than external factors. Among those who cited external factors, population growth, economic/ employment growth, and worsening traffic congestion were the most frequently mentioned. Only a few respondents cited policies or programs to increase the cost of driving (these concerned increases in parking costs); that such measures were rarely cited probably reflects the fact that such policies are, in most cases, beyond the control of transit managers, and not that they are ineffective in motivating transit use.

While one must keep in mind that the findings of this survey are limited to the perceptions of transit managers responding to the survey, this study does offer an illuminating snapshot of the strategies pursued by transit systems that added riders during the 1990s. In particular, transit systems have employed a wide array of fare and service innovations coincident with increasing patronage. While the causality between system changes and ridership growth is only hypothesized by 
respondents to this survey, the respondents are, as a group, professionals for whom the relationship between transit service provision and transit service consumption is a daily (pre)occupation. As such, the findings here, at the very least, reflect the views of informed observers. As the next step in this research, we plan to complement this study with a statistical analysis of national ridership, service provision, and economic data in an effort to measure the relative effects of both internal and external factors on transit ridership in the 1990 s.

\section{Acknowledgments}

This research was funded by the Mineta Transportation Institute, and the authors are grateful for this support. The authors thank Brent Boyd and Douglas Kolozsvari for their assistance in the project. Any errors or omissions are the responsibility of the authors. 


\section{Endnotes}

1. The NTD reports the number of unlinked trips. According to the American Public Transportation Association (APTA 2001), an unlinked transit trip is a trip on one transit vehicle. A person riding one vehicle from origin to destination takes one unlinked trip; a person who transfers to a second vehicle takes two unlinked trips; a person who transfers to a third vehicle takes three unlinked trips. APTA estimates that the number of people riding transit on an average weekday is 45 percent of the number of unlinked transit passenger trips.

2. These numbers are based on the Federal Transit Administration's NTD and differ somewhat from the longer-term ridership statistics provided by APTA cited earlier. This is because the NTD includes only those agencies that receive federal funds and thus report to the FTA, while APTA estimates ridership for 6,000 transit systems, whether or not they report to the NTD. Most data cited in this study are drawn from the NTD, supplemented by the U.S. Census and the Nationwide Personal Transportation Survey.

3. Deep discount fare policies stratify transit markets into segments based on two primary factors: (1) frequency of use and (2) sensitivity to cost (Fleishman 1993). Such policies generally offer a per ride discount for the purchase of a multiple-rides pass or transit card, aiming to induce potential riders with low usage and high price sensitivity to increase overall transit patronage.

4. The NTD, formerly known as Section 15 database, is a system of accounts and records reported annually by the more than 500 transit systems that receive federal transit subsidies. These transit systems are required to report a wide range of data to the FTA concerning the finance and operation of their system. Although the NTD is clearly the best, comprehensive, cross-sectional transit data source, it is not without limitations. For example, not all systems report data to the NTD because systems that do not receive federal subsidies are not required to report. However, the transit systems operating the vast majority of service and carrying the vast majority of passengers in the United States do report to the NTD. The authors estimate that, nationwide, 93 percent of all transit ridership is counted in the NTD. The APTA estimates a grand total of 9.17 billion unlinked passenger trips taken in 1999, while the FTA's NTD reports that 8.52 billion unlinked passenger trips were taken $(8.52 \div 9.17=0.93)$. APTA's ridership estimates are available online at http://www.apta.com/stats/ ridershp. 
5. Such as bus, trolleybus, light rail, heavy rail, commuter rail, ferryboat, cable car, inclined plane, monorail, jitney, or automated guideway.

6. For the many agencies that provide both fixed-route and demand-response or taxi services, the authors included data only on the fixed-route modes (so the data analyzed here may differ slightly from NTD published "totals" for each agency).

7. Most transit researchers would agree that linked trips (i.e., trips that include transfers) and passenger miles data (i.e., total trips * average trip length) are more telling and less biased measures of transit use. But reliable, comparable cross-sectional data for either of these measures of transit service consumption are simply not available. Lacking data on these measures, the authors (and nearly all previous research on transit ridership) use unlinked trip data.

8. In some cases, open-ended questions were grouped together based on similar responses.

9. Some observers may be surprised to learn that increasing ridership is typically not an explicit goal of transit systems, since it often conflicts with service utilization and budgetary goals. Nevertheless, some transit systems surveyed reported that increasing ridership is among their objectives. For example, the Cleveland $(\mathrm{OH})$ LAKETRAN reported a goal of serving 1 million riders in 2001; the Antelope Valley (CA) Transit Authority intends to increase transit ridership by 5 percent per year; Chicago (IL) Metra hopes to increase growth 2 to 3 percent per year; Vallejo (CA) Transit intends to increase midday and weekend ridership on its ferry system; and the Orange County (CA) Transportation Authority has estimated that the system must grow by 50 percent in the next 5 or 6 years to accommodate forecast ridership.

10. A detailed review of universal fare payment programs in universities-also known as unlimited access - is given in Brown et al. (2001). The authors found that at the universities studied, student transit ridership increases ranged between 71 percent and 200 percent during the first year of unlimited access, and growth in subsequent years ranged between 2 percent and 10 percent per year.

11. Because partnerships were reported mostly in discussions of other programs and service changes, respondents often did not specify the degrees of effectiveness of partnership efforts. Table 6 , therefore, does not include relative importance. 
12. Because most amenities were reported as "other" service changes, respondents did not provide their views of each amenity's degree of effectiveness in increasing ridership. Table 7, therefore, does not indicate the relative importance of the programs.

13. This relationship between fast food and transit ridership has, to the authors' knowledge, been completely ignored in previous research. 


\section{References}

American Public Transit Association. 1999. APTA ridership report-fourth quarter 1999. Washington, DC: APTA. Available online at: http://www.apta.com/stats/ ridershp/index.htm.

American Public Transit Association. 2001. APTA ridership report-fourth quarter 2001. Washington, DC: APTA. Available online at: http://www.apta.com/stats/ ridershp/index.htm.

Brown, J., D. B. Hess, and D. C. Shoup. 2001. Unlimited access. Transportation 28(3):233-267.

Cervero, R. 1990. Transit pricing research: A review and synthesis. Transportation 17:117-139.

Crane, R. 2000. The impacts of urban form on travel: An interpretive review. Journal of Planning Literature 15:3-23.

Elmore-Yalch, R. 1998. A handbook: Using market segmentation to increase transit ridership. Transportation Research Board TCRP Report 36. Washington, DC: National Academy Press.

Federal Highway Administration. 1995. Nationwide personal transportation survey. Washington, DC: U.S. Department of Transportation, Federal Highway Administration. Available online at: http://www-cta.ornl.gov/npts/1995/doc/ index.shtml.

Fielding, G. J. 1995. Transit in American cities. In The geography of urban transportation. 2d ed. S. Hanson, ed: 287-302. New York: Guilford Press..

Fleishman, D.1993. Recent experience with deep discounting. Washington, DC: Federal Transit Administration, Operations and Service Planning Symposium (December). Available online at: http://www.fta.dot.gov/library/technology/symops/ fleishma.htm.

Fleishman, D., N. Shaw, A. Joshi, R. Freeze, and R. Oram. 1996. Fare policies, structures, and technologies. TCRP Report No. 10. Washington, DC: Transportation Research Board.

Gomez-lbanez, J. A. 1996. Big-city transit ridership, deficits, and politics: Avoiding reality in Boston. Journal of the American Planning Association 62(1):30-50. 
Hartgen, D. T., and M. L. Kinnamon. 1999. Comparative performance of major U.S. bus transit systems: 1988-1977. Charlotte, NC: Center for Interdisciplinary Transportation Studies, University of North Carolina at Charlotte.

Kain, J. F., and Z. Liu. 1995. Secrets of success: How housing and San Diego transit providers achieved large increases in transit ridership. Washington, DC: Federal Transit Administration.

Kain, J. F., and Z. Liu. 1996. An econometric analysis of determinants of transit ridership: 1960-1990. DOT-VNTSC-FHWA-98-6. Cambridge, MA: U.S. Department of Transportation, Volpe National Transport Systems Center.

Oram, R. 1990. Deep discount fares: Building transit productivity with innovative pricing. Transportation Quarterly 44(3):419-440.

Pisarski, A. 1996. Commuting in America II: The second report on commuting patterns and trends. Landsdowne, VA: Eno Transportation Foundation.

Pushkarev, B., and J. M. Zupan. 1977. Public transportation and land use policy. Bloomington, IN: Indiana University Press.

Rosenbloom, S. 1998. Transit markets of the future: The challenge of change. Transportation Research Board TCRP Report 28. Washington, DC: National Academy Press.

Sale, J. 1976. Increasing transit ridership: The experience of seven cities. Washington, DC: Urban Mass Transportation Administration.

Taylor, B., and W. S. McCullough. 1998. Lost riders. Access 13:26-31.

Transit Cooperative Research Program. 1998. Strategies to attract auto users to public transportation (40). 


\section{About the Authors}

Daniel BALdWin Hess (dhess@ucla.edu) is a postdoctoral scholar at the University of California, Los Angeles (UCLA) Institute of Transportation Studies.

ALuson YOH (ayoh@ucla.edu) is a doctoral student in UCLA's urban planning program and a member of the Los Angeles County Metropolitan Transportation Authority governing board.

HiROYUKI ISEKI (hiseki@ucla.edu) is a doctoral candidate in UCLA's urban planning program.

BRIAN TAYLOR (btaylor@ucla.edu) is associate professor of urban planning and director of the UCLA Institute of Transportation Studies. 